\title{
An adapted Porter Diamond Model for the evaluation of Transnational Education host countries
}

\author{
Vangelis Tsiligiris \\ Nottingham Business School, Nottingham Trent University, Nottingham, UK
}

\begin{abstract}
Purpose - The purpose of this study is to propose an adapted Porter Diamond Model (PDM) that can be used by Transnational Education (TNE) countries and institutions as an analytical framework for the strategic evaluation of TNE host countries in terms of attractiveness for exporting higher education.
\end{abstract}

Design/methodology/approach - The study uses a literature review to adapt the PDM in the context of TNE host countries. A pilot study of adapted PDM is conducted for China and Malaysia. Available country data is collected via desk-study.

Findings -The pilot application of the adapted PDM revealed no major issues or failings. Only some minor difficulties in the identification of appropriate data which can be resolved with the use of alternative metrics. The results from the analysis of the two countries, indicate that China and Malaysia are both suitable TNE host countries for expanding existing and developing new activities. This also indicates the proposed use of the adapted PDM is suitable to effectively evaluate TNE host countries.

Practical implications - This adapted model can be used by TNE exporting institutions and countries to access the suitability of prospective TNE host countries for education export. Also, it can be used to evaluate the future risks for existing TNE activities. TNE host countries can use the model to strengthen their attractiveness for education import or to plan of becoming education hubs.

Originality/value - Considering the scale and the expected growth of TNE, as well as the lack of strategic analysis tools for TNE; the proposed model provides a valuable practical tool to aid strategic planning at institutional and country level.

Keywords - transnational education, strategic analysis, diamond model,

Paper type - Research paper 


\section{Introduction}

Transnational Education (TNE) offers a range of benefits, for both exporting and host institutions and countries, however, it also involves significant financial and reputational risks. As such, TNE activities should be carefully planned, pursued, and monitored as part the higher education institution's (HEI) internationalisation strategy and activity. Nevertheless, often TNE activities are pursued as result of connections and personal initiatives by academics and researchers in exporting and host countries (McBurnie and Ziguras, 2007). There is the recommendation for thoughtful strategic analysis and senior management engagement as a way to minimise the risks and maximise the benefits of TNE activities (Emery and Worton, 2014). By adapting Porter's Diamond Model (PDM), this study aims to propose a practical analytical framework that TNE exporting countries and institutions can use for the strategic evaluation of TNE host countries in terms of attractiveness for exporting higher education.

\section{Literature review}

\section{Models to evaluate strategic decisions in TNE}

There are various models to analyse and discuss TNE activity at both national and institutional levels. These models offer alternative perspectives and consider an array of different factors, vested in the internal and external environment of the HEIs involved. Healey (2015) proposes the "4F" typology in an effort to map the four core TNE modes distance learning, International Branch Campuses (IBCs), franchising, and validation against reputational risk. This model is a useful analysis tool but it focuses only on risk and does not provide insights into the strategic aspects of the different TNE modes. Shams and Huisman (2012) refer to Dunning's OLI (Ownership, Location, Internationalisation) model ${ }^{\mathrm{i}}$ to evaluate the different types of TNE and institutional strategies, indicating that strategic resource transfer management affects the immediate and longer-term success of transnational education activity. Wilkins and Huisman (2012) use institutional theory - with emphasis on Scott's three pillars of institutions (1995 cited in Wilkins and Huisman, 2012, p.3) - as the analytical framework for examining transnational education decisions and strategies of HEIs. Their prime focus is IBCs and they conclude that "a mix of macro social forces and individual or organizational agency influence the strategic decision-making of HEIs" (p.13). Wilkins (2016a) proposed a framework that strategic decision makers can refer to when evaluating opportunities to develop IBCs in foreign countries, based on the strategy tripod approach. This approach combines the institutional, industry and resource based views. The framework recognizes that national influences (the environmental and industry factors) should 'fit' with the institution's resources and competencies (the organisational factors). Ilieva et al (2017) have developed a policy analysis framework to evaluate the national policies on three aspects of international higher education (IHE) - student mobility, research collaboration, and transnational education. This policy analysis framework focuses on mapping the IHE policy context in different countries and support strategic decisions by HEIs and government departments.

Although the above models provide valuable insights, there is lack of consideration of wider and diverse factors that affect the success of TNE ventures. For example, there is little consideration of issues such as student presage factors, availability of human resources, demographics, and income. Ghemawat (2001), in his work "Distance Still Matters", offers an interesting model that acknowledges the wider aspects that impact the success of cross-border activities. He is proposing to acknowledge the impact of cultural; administrative and political; geographic; and economic distances when making decision on cross-border activities. 
Ghemawat's model (2001) has been applied in a range of different industries but not in IHE or TNE.

\section{Porter's Diamond Model}

Despite the extensive criticism it has received, Michael Porter's Diamond Model (PDM), in figure 1 below, remains one of the most prominent models of strategic analysis. The purpose of the model is to facilitate the understanding of firms' competitive advantage in the context of the industry and the nation they operate (Porter, 1990). Porter, through his model, aims to explain why certain countries are very successful in specific industries. To do that, he considers the firm as the driver of national competitiveness. Thus, the diamond refers to the cluster - this is the environment closer to the firm and not the abstract wider national environment.

As outlined in the figure 1 below, the model considers four determinants of national competitive advantage: 1 ) factor conditions; 2) demand conditions; 3 ) related and supporting industries; and 4) firm strategy, structure, and rivalry. Additionally, government and chance are two determinants that affect the national environment and as such have an indirect impact on the four key determinants of competitive advantage.

\section{Factor conditions}

According to Porter (1990), the availability of the basic factors of production (i.e. labour, land, natural resources, capital, infrastructure) impacts the economic activity. It is the availability of these factors that will determine the balance between exports and imports. However, Porter considers the advanced factors as more important to influence a country's competitive advantage. Examples of these advanced factors include a highly-trained labour force and the national communications infrastructure. The existence of these advanced factors, as well as the country's capability to develop them, will define a country's competitive advantage.

\section{Demand conditions}

Despite the globalisation of markets, home demand conditions remain a critical factor in shaping a country's competitive advantage. The model considers the quality of the home demand (e.g. home customers demanding higher standards of products/services) as a catalyst to the quality improvement of firms (Porter, 1990). The quality and sophistication of home demand is shaped by values (e.g. cultural, ethical) and conditions (e.g. regulations).

\section{Related and supporting industries}

The PDM considers the existence of successful networks of supporting industries as having a positive spillover effect (Porter, 1990). The presence of related and supporting industries, which are internationally competitive, provides effective and efficient supply of costeffective inputs. Also, it promotes innovation and improvements through the increased flow of information and technology. One example is the Silicon Valley cluster comprising "semiconductor, computer, software, and venture capital firms" (Grant, 2010, p. 377).

\section{Firm strategy, structure, and rivalry}

The competitive advantage of clusters will depend upon the firms' strategies, structure, and rivalry. Domestic rivalry, according to Porter (1990), affects all other factors of PDM and as such it has the most significant impact on competitiveness. The intensity of rivalry will push firms to review their operation (e.g. cost structures), quality, and innovation. Porter (1990) considers domestic rivalry to be more important than international rivalry because the former 
is more intense and direct. One example is the success of the Japanese auto and electronics clusters which is driven by intense domestic rivalry (Grant, 2010).

\section{The role of government and chance}

In the PDM, chance reflects events that are unpredictable and uncontrollable by firms. Some examples of such event are wars, significant changes in exchange rates, physical phenomena, and disruptions in the flow of supply of production inputs (Porter, 1990). The competitive advantage of firms will depend upon their resilience and adaptability to these unforeseen events.

The government has a fundamental impact across the entire PDM. However, Porter (1990) sees the government as a facilitating and not as a creating force of competitive advantage. Instead, government intervention should be minimised and firms should be left to pursue their initiatives. The role of the government is to push and challenge firms by removing barriers to competition and promoting the creation of specialised factors.

\section{Figure 1. Porter's Diamond Model}

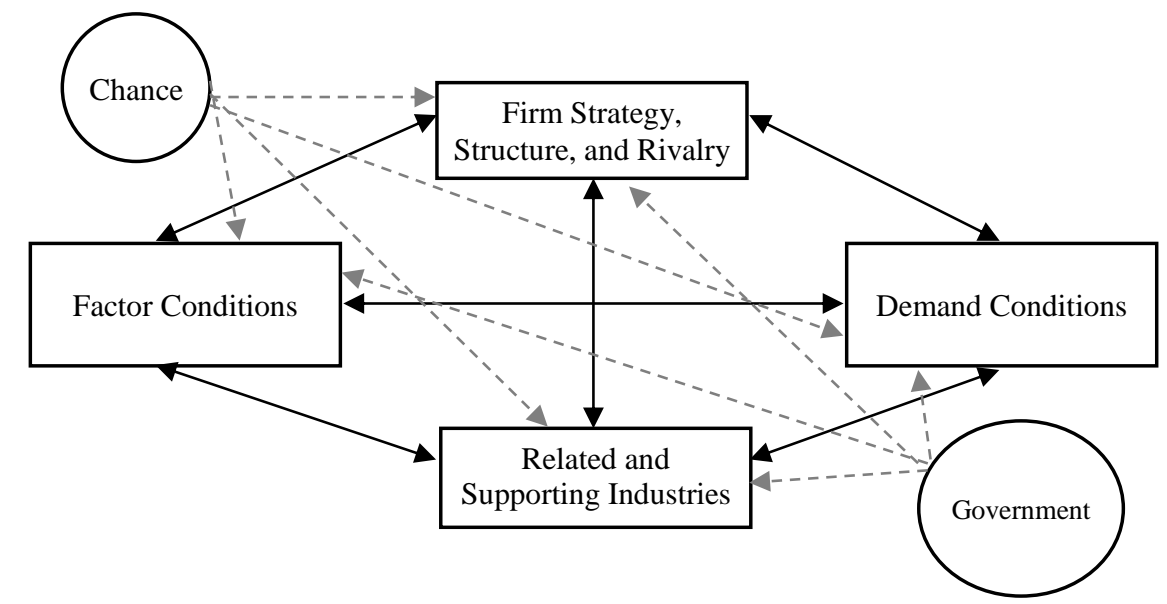

\section{Criticism on PDM}

The PDM has received substantial criticism by various scholars. Dunning (1993) argues that Porter, in his PDM, fails to acknowledge the impact of globalisation on the ability of nations to create cross-border synergies and hence improve their competitiveness. As response to this, Rugman and D'Cruz (1993) offer the "double diamond" - consisting of domestic and foreign diamonds - as a more effective tool for developing global and sustainable competitive advantage.

Another area of criticism relates to ambiguity around the specific links between the four elements of the model and how these determine national success (Moon et al., 1995). For example, factor conditions have been associated with different impact on a nation's international competitiveness. Also, Grant (1991) questions the power of the model to predict competitive advantage.

However, as explained by Grant (1991), beyond its limitations, the PDM has a unique strength to combine three levels of analysis: the firm, the industry, and the nation. As such, despite the criticism, the PDM has been used to evaluate competitive advantage in various industries and countries. In higher education (HE), the PDM has been used to investigate several aspects, including research competitiveness (Curran, 2000); Countries' comparative advantages in academic disciplines (Harzing and Giroud, 2014); and the competitiveness of the national HE systems (Stonkiene et al., 2016). Nevertheless, the PDM has not been used in the context of TNE, and from the TNE exporting country/institution's perspective, to evaluate a TNE host country as export destination. 


\section{The need for an adapted PDM for TNE}

Exporting higher education, through TNE activities, is a complex process whereby its success is heavily dependent on a range of factors and conditions in the importing country. The American Council on Education (ACE) (2015) suggests that the wider social, political, and cultural conditions in the importing country will affect the sustainability of TNE activities, and thus should be scrutinised as part of the initial due diligence process. As highlighted in the literature review above, the existing models focus on reputational risk (Healey, 2015), IBCs (Wilkins and Huisman, 2012; Wilkins, 2016a) and the regulatory framework of host countries (Ilieva et al, 2017). An adaptation of the PDM - reflecting the wider factors affecting the sustainable development of TNE - could serve as framework for a holistic evaluation of the TNE host country's environment. This adapted PDM can support strategic and operational decision-making of potential stakeholders (e.g. exporting HEIs, and exporting, as well as importing, countries).

\section{An adapted PDM for the evaluation of TNE host countries}

Although the conventional use of PDM is to evaluate the competitive advantage of exporting countries, it can be equally useful to evaluate the attractiveness of importing countries as export destinations. In this study, the purpose of utilising PDM of national competitive advantage is to develop a tool for the systematic analysis of TNE host countries. In this context, "competitive advantage" is defined as a set of factors that create a prosperous environment for the establishment of TNE activities and ventures. By evaluating the TNE host country's contextual factors, exporting countries and institutions will be able to develop their national and corporate strategy, respectively, for TNE. However, the outcomes of the adapted PDM model can also be used by TNE host countries to identify strengths and weaknesses in their effort to attract TNE activities, transform to exporting countries of TNE, or becoming education hubs.

The original PDM is adapted to reflect the factors that impact the success and sustainability of TNE activities from the viewpoint of the TNE exporting institution/country. For the purposes of TNE application, the relevant literature is reviewed to update the components within each of the four factors of the PDM. The components selected within each factor are indicative of the range of possible metrics that can be considered for an adapted PDM for the evaluation of TNE host countries. Therefore, the composition of the model below should be considered as dynamic and not fixed. The metrics have been selected on the basis of: 1) their availability for as many countries as possible; 2) their open access; and 3) the robustness of their methodology. As such, some of the metrics might not be entirely TNE-specific (e.g. "ease of doing business") but satisfy the above criteria, hence allowing an efficient systematic direct comparison between alternative TNE host countries. These generic metrics can be complemented by TNE-specific qualitative factors that exist in each country (e.g. special arrangements for the establishment of TNE activities - see for example Dubai and the Knowledge Park).

The adapted PDM is summarised in figure 2 below and analysed in the next paragraphs. 
Figure 2. An adapted model for the evaluation of TNE host countries

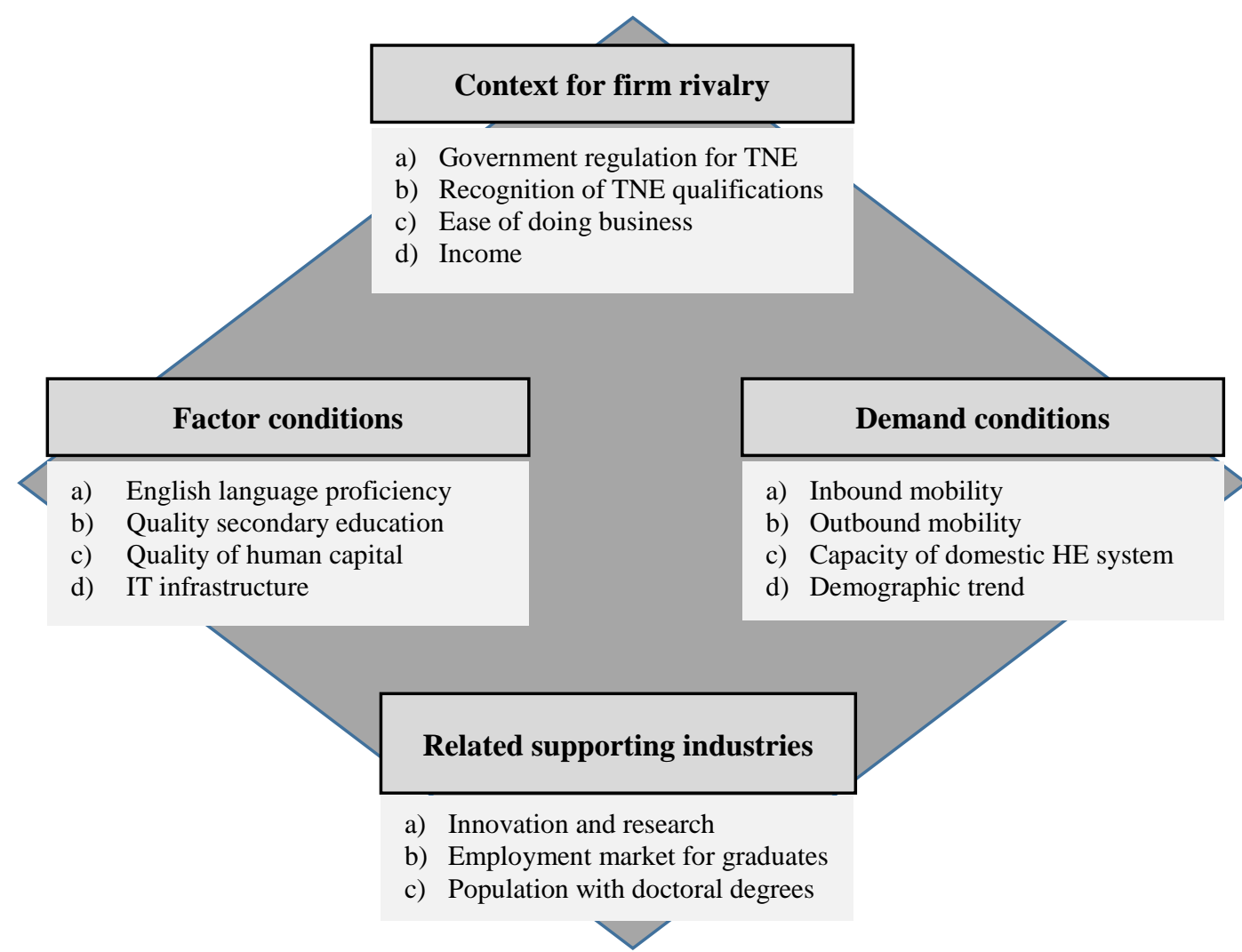

\section{Factor conditions}

According to the initial version of the model, factor conditions refer to the factors necessary in the production process (Porter, 1990). These are usually grouped under human resources, knowledge resources and infrastructure. In this study factor conditions refer to the factors that help the establishment, development, and sustainability of TNE in a host country.

a) English language proficiency. The level of English language knowledge in a TNE host country plays a significant role on whether TNE activities can be pursued or not (Wilkins and Urbanovič, 2014). This is especially important for English speaking TNE exporting countries, such as the UK and Australia, where the national quality assurance bodies (e.g. QAA) tend to develop stricter regulations about the language of delivery of TNE programmes (QAA, 2012). Additionally, delivering TNE programmes in other languages - despite having a potentially positive impact on learners' performance - imposes additional costs to comply with the quality assurance requirements (e.g. translations, nonEnglish speaking moderators). To assess the TNE host country's English language proficiency, the EF EPI ranking will be used (Education First, 2016).

b) Quality of secondary education. According to Biggs (1988) student presage factors, and primarily the previous education experience, will have a significant impact on the educational process outcomes. This applies without exception to all levels of education, including TNE (Tsiligiris, 2015). In TNE, therefore, the secondary education standards of students will impact the success and sustainability of programmes offered across borders. To measure the quality of secondary education, the OECD PISA score of the TNE host country can be used (OECD, 2015a). 
c) Quality of human capital. One of the main challenges faced by TNE exporting institutions is to source locally appropriate staff to support the TNE delivery and operation (Stafford and Taylor, 2016). The existence of high quality human capital in a TNE host country, allows the consideration of the full spectrum of TNE modes. For example, if high quality human capital is available locally, a TNE exporting institutions can explore the potential to establish an IBC. The indicator proposed for measuring the quality of human capital in the TNE host country is the Human Capital Index produced by the World Economic forum (WEF, 2016).

d) IT infrastructure. Internet access is critical to support administrative and teaching activities of TNE (Lawton and Jensen, 2015). Additionally, the existence or not of suitable IT infrastructure, at national and regional levels, will determine the type of TNE to be deployed (Lawton and Jensen, 2015). For example, although online delivery may be the preferred mode of TNE for many exporting institutions, this will not be feasible in certain parts of the world due to poor IT infrastructure at national level. Two indicators can be used to assess the state of the IT infrastructure: a) internet users per 100 people World Bank indicator (World Bank, 2017a); and b) Average Connection Speed (IPv4) an indicator by Akamai's "state of the internet" (Akamai, 2017).

\section{Related supporting industries}

The existence of appropriate suppliers and distribution networks are some of the factors the original PDM considers as related supporting industries. For TNE the key supporting industries relate to the availability of appropriate human talent and research activity to facilitate basic (e.g. Franchising; validation) as well as more advanced forms of TNE (e.g. IBCs; joint venture research centres). Additionally - considering the increasing emphasis on employability prospects by students - the employability of TNE graduates in the host country will be a critical aspect for the sustainability of TNE activities.

a) Innovation and research activity. The level of innovation and research activity in a TNE host country will impact the sustainability of TNE activities. Countries high in innovation and research, tend to attract businesses and international talent. This creates a positive environment where the presence of foreign universities, via TNE activities, enable a range of synergies; one example is the city of Suzhou in China. The Global Innovation Index (GII) can be used as the indicator to measure this factor (Dutta et al., 2017).

b) Employment market for graduates. One of the key attributes of HE's "value for money" is the employability of graduates (Tomlinson, 2016). In a country where there are high employment rates for graduates, prospective students will seek ways to differentiate themselves (Bardhan et al., 2013). Obtaining a foreign degree via TNE will be one of the ways to gaining competitive advantages in the employment market. This means a stronger demand for TNE and better prospects for its sustainable development in the TNE host country. The indicator to measure this can be "Employment by education level: Tertiary, $\%$ of 25-64 year-olds" maintained by the OECD (2015b).

c) Population with doctoral degrees. The availability of suitable academic staff in a TNE host country will impact the range of TNE activities that can be pursued (British Council and DAAD, 2014; Lindsay and Antoniou, 2016; Shams and Huisman, 2012). However, a critical aspect will be the availability of suitable workforce to support not only the core 
teaching activity, but to enable the operation of an IBC where research activity is expected. For example, the availability of doctoral graduates may allow to develop research activity as part of an IBC. Also, it will impact the life-cycle of TNE in this country. For example, after a certain point, a franchise provision has grown enough to justify the consideration of a jointed venture between the partner institution and the exporting institution. One of the metrics for this factor can be UNESCO's "The percentage of population (age 25 and over) with a completed doctoral or equivalent degree (ISCED 8)"(UNESCO UIS, 2017).

\section{Demand conditions}

The initial PDM considers demand conditions as a key determinant of the national competitive advantage (Porter, 1990). In the context of this study, demand conditions refer to those factors that shape the demand for TNE in a host county. Demand for TNE is a complex and dynamic issue. As such, it is not possible to identify a universal set of indicators that will predict TNE demand accurately across different TNE host country. Nevertheless, research (HE Global, 2016; Marginson et al., 2011) shows that some of the key factors impacting demand for TNE are: 1) the inbound and outbound mobility; 2) the capacity of the HE system in the host country; and 3) the demographic trends.

a) Inbound mobility. One of the key determinants for the demand of TNE programmes in a host country is mobility dynamics (Lawton and Katsomitros, 2012; Tsiligiris, 2014).

These mobility dynamics, and particularly the inbound mobility of international students, will not only determine the volume but also the type of TNE provision. For example, if a country is a destination for international student, then supply of HE will be welldeveloped - both in terms of volume and quality. For existing TNE activities this may pose opportunities but for potential new entrants it creates a more competitive environment. UNESCO's (2017) “inbound mobility rate", and year-on-year analysis, can be used to assess the host country's inbound mobility trend .

b) Outbound mobility. TNE is often considered a substitute to outbound mobility, but research has shown that this is not always the case (Levatino, 2016; Tsiligiris, 2014). However, outbound mobility, and especially its year-on-year trend, provides a good indication about the type of TNE required in the host country. For example, if outbound mobility increases year-on-year then this may imply a persistent and growing gap between supply and demand, which creates opportunity for less complex forms (e.g. franchising, validation) of TNE. In contrast, if outbound mobility decreases year-on-year, there might be an increase in the capacity of the domestic HE system, which dictates the need for advanced forms of TNE (e.g. IBC, flying-faculty). UNESCO's (2017) "outbound mobility rate", and year-on-year analysis, can be used to assess the host country's outbound mobility trend.

c) Capacity of domestic HE system. The capacity of the TNE host country's HE system will define the size and type of demand for TNE (HE Global, 2016; McBurnie and Ziguras, 2007). For example, a country with low HE capacity allows opportunities for franchising, distance learning, or validation arrangements as a quick way to close the gap between supply and demand for HE. In contrast, a country with high HE capacity will be suitable for advanced forms of TNE such as IBCs and joint ventures. UNESCO's (2017) Gross enrolment ratio (GER) - Tertiary, can be used to measure the capacity of the HE system in the TNE host country. 
d) Demographic trend. One of the key determinants for the demand of HE is demographics and especially the secondary education age group (e.g. 13-18 year-olds) (Sa et al., 2004). Using United Nations data about population growth in the future (UN, 2017), TNE exporting institutions can identify host countries where demand for HE is likely grow as result of the larger 13-18 year-olds age group. This is a critical factor for the sustainability of TNE activities and especially capital-intensive (e.g. IBCs) forms of delivery.

\section{Context for firm rivalry}

According to the original model, the industry context, the strategy of firms, and the existing rivalry will shape the competitiveness of the industry (Porter, 1990). In the case of TNE, this dimension is considered to encapsulate the factors affecting the sustainable development of TNE activities in the host country. This refers to the TNE host country's legislative context and the role of government. Additionally, this dimension considers the factors that affect the processes required to setup business activity as well as the purchasing power in the TNE host country.

a) Government regulation for TNE. Certain countries do not allow any TNE activities, prohibit certain types of TNE (e.g. IBCs), or impose restrictions on the number of providers (Ziguras, 2016). Thus the "government regulation for TNE activities" will have a direct impact on the firm rivalry. The assessment of the regulatory framework in the TNE host country will entail consideration of any existing policies and legislation for TNE. This can be complemented and triangulated with secondary data from publications such as "the Shape of Global HE" (Ilieva et al., 2017).

b) Recognition of TNE qualifications. It is known (Hoare, 2012; Wilkins, 2016b) that TNE students are attracted by the added value of a foreign degree qualification. There have been several instances were governments in TNE host countries (e.g. Greece) have been reluctant to recognise qualifications obtained via TNE programmes (Ziguras and McBurnie, 2015). This creates negative student and graduate perceptions about the value of TNE, which in turn creates imbalances in the rivalry between TNE providers and domestic HEIs. Data can be obtained by the TNE host country's NARIC website and complemented by secondary data by the exporting country's QA agency (e.g. QAA for the UK).

c) Ease of doing business. Certain types of TNE require physical presence which in turn requires the setting up a legal entity in the TNE host country (Verbik, 2007). One example is the need to develop legal entities to support the development of IBCs. However, depending on the country, there might be barriers that prevent or delay setting up these legal structures. World Bank's index of "Ease of doing business" is a suitable indicator to assess the existence of these barriers (World Bank, 2017b).

d) Income. International student's decision about destination country, study institution, and course is partially determined the GDP per capital in the country of origin (Yang and Wang, 2016). TNE is considered a form of international education and therefore some argue it forms an economical alternative to international student mobility (Levatino, 2016). Nevertheless, depending on the GDP per capital, certain forms of TNE might be less competitive than others. For example, programmes offered via IBCs tend to be more expensive to offer via franchise arrangements. It will be therefore critical to compare the GDP per capital in the TNE exporting and host countries. Expressing the GPD per capital in the TNE host country as a percentage of the GPD per capital in the TNE exporting 
country, provides a meaningful indication as to how the purchasing power compares between the two countries. The GPD per capital indicator can be obtained by the World Bank (2017a). It should be noted that the GPD per capital is a mean value and it does provide information about the income distribution. Considering that many TNE host countries tend to have skewed income distribution, the validity of the outcomes of the metric will be subject to this. 


\section{Pilot application of the adapted PDM: China and Malaysia}

\section{Methodology}

A pilot study is used to demonstrate a practical application of the adapted PDM model in analysing TNE hosts countries. The focus of analysis in this pilot study is the UK as major exporting country and China and Malaysia as two of the major TNE host countries. The data collection is done through a desk-study approach and the data collected represents the most recent available data for each of the countries in the pilot study. Where country data is not available for a specific indicator, an alternative indicator is used.

\section{Findings}

\section{Factor conditions}

a) English language proficiency

Considering the EF EPI ranking for 2016, and as summarised in table 1, the English language proficiency in China is low whereas in Malaysia is high (Education First, 2016). For TNE exporting institutions this implies that Chinese TNE students, may need additional language support as part of their TNE programme.

b) Quality of secondary education

Chinese secondary education PISA 2015 scores are slightly above the OECD average (OECD, 2015a). Malaysia does not participate in PISA. However, the Malaysian secondary education has undergone a number of substantial changes that reflect the country's strategy to become a knowledge-based economy (Grapragasem et al., 2014). As summarised in table 1 , both countries have a strong secondary education system which reassures the existence of appropriate minimum student standards for TNE.

c) Quality of human capital

Malaysia ranks higher than China in the quality of human capital index for 2016 (WEF, 2016). This may imply that TNE exporting countries will find it less challenging to source appropriate academic and administrative staff in Malaysia than in China and particularly in India. Additionally, it may also imply that TNE activities in China will require more investment in staff development activities.

\section{d) IT infrastructure}

The IT infrastructure is better developed in Malaysia where in $201571 \%$ of people have access to internet, in comparison to 50\% in China (World Bank, 2017a). Also, Malaysia has faster internet connection speed in comparison to China (Akamai, 2017). In this context, certain forms of TNE, such as distance learning, may not be appropriate for China. IT infrastructure in Malaysia appears to be best suited to support TNE ventures (e.g. partnerships, IBCs) where communication with the TNE exporting institution's IT network is vital. 
Table 1. Factor conditions analysis for China and Malaysia

\begin{tabular}{|c|c|c|c|c|}
\hline Factor conditions & Metric & Year of latest data & China & Malaysia \\
\hline $\begin{array}{l}\text { a) English language } \\
\text { proficiency }\end{array}$ & EF EPI ranking & 2016 & $\begin{array}{l}\text { Low } \\
\text { Proficiency }\end{array}$ & $\begin{array}{l}\text { High } \\
\text { Proficiency }\end{array}$ \\
\hline $\begin{array}{l}\text { b) Quality of secondary } \\
\text { education }\end{array}$ & $\begin{array}{l}\text { PISA mean score } \\
\text { (science, reading, and } \\
\text { mathematics) }\end{array}$ & 2015 & $518 ; 494 ; 531$ & Not available \\
\hline $\begin{array}{l}\text { c) Quality of human } \\
\text { capital }\end{array}$ & Human Capital Index & 2016 & $67.81(71 / 130)$ & $74.26(42 / 130)$ \\
\hline \multirow{2}{*}{ d) IT infrastructure } & $\begin{array}{l}\text { Internet users per } 100 \\
\text { people }\end{array}$ & 2015 & 50.3 & 71.1 \\
\hline & $\begin{array}{l}\text { Average Connection } \\
\text { Speed (Mbps) }\end{array}$ & 2017 & $\begin{array}{l}\text { 6.3 Mbps (Rank } \\
89 \text { ) }\end{array}$ & $\begin{array}{l}8.2 \mathrm{Mbps} \\
\text { (Rank 66) }\end{array}$ \\
\hline
\end{tabular}

\section{Related supporting industries}

a) Innovation and research

As summarised in table 2 below, China has a higher Global Innovation Index (GII) score (50.57) than Malaysia and is ranked 25 out of 128 countries (Dutta et al., 2017). China is evaluated as being very strong in sustaining investments in research and development (R\&D). Also, the country is the first middle-income economy to join the top 25 of the Global Innovation Index. In contrast, Malaysia, another middle-income economy, is currently in place 35 verging away from the top 25 list. By this measurement, China appears to be more suited for research intensive TNE partnerships.

b) Employment market for graduates ${ }^{i i}$

In China, graduate employment is low and there is evidence to suggest that the expansion in the supply/access of HE in China has caused higher graduate unemployment ( $\mathrm{Li}$ et al., 2014). This may mean a positive prospect for the provision of TNE, as foreign degrees may be considered by prospective students in China as a way to gain competitive advantages in the graduate employment market. In Malaysia, although it is reported that the employability of graduates is low, it seems that "those enrolled in transnational private education are rated better than those from public universities" (Cheong et al., 2016, p.2253). This creates very positive prospects for the further expansion and longer term sustainably of TNE in Malaysia.

c) Population with doctoral degree $e^{i i i}$

Despite the high growth in the number of PhD graduates during the past 20 years in China, there are concerns about the quality of doctoral education (i.e. lack of doctorate qualified faculty) (Huang, 2017). The Malaysian government has a plan to have 60,000 $\mathrm{PhD}$ graduates by 2023 and to facilitate this plan the government provides funding via the programme "MyBrain15" (MIDA, 2017). Therefore, as summarised in table 2, TNE exporting countries can consider both China and Malaysia as potential growth markets for joint PhD programmes. 
Table 2. Related supporting industries analysis for China and Malaysia

\begin{tabular}{|l|l|l|l|l|}
\hline $\begin{array}{l}\text { Related } \\
\text { supporting } \\
\text { industries }\end{array}$ & Metric/source & Year of latest data & China & Malaysia \\
\hline $\begin{array}{l}\text { a) } \\
\text { Innovation } \\
\text { and research }\end{array}$ & $\begin{array}{l}\text { Global Innovation } \\
\text { Index (GII) }\end{array}$ & 2017 & 50.75 (Rank 25) & 43.36 (Rank 35) \\
\hline $\begin{array}{l}\text { b) } \\
\text { Employment } \\
\text { graduates }\end{array}$ & $\begin{array}{l}\text { Condition of } \\
\text { employment market } \\
\text { for graduates } \\
\text { /Various } \\
\text { publications }\end{array}$ & 2016 & $\begin{array}{l}\text { High } \\
\text { unemployment for } \\
\text { HE graduates }\end{array}$ & $\begin{array}{l}\text { "Unemployable" } \\
\text { graduates. Better } \\
\text { prospects for TNE } \\
\text { graduates. }\end{array}$ \\
\hline $\begin{array}{l}\text { Population } \\
\text { with doctoral } \\
\text { degree }\end{array}$ & $\begin{array}{l}\text { Size and quality of } \\
\text { doctoral } \\
\text { education/various } \\
\text { publications }\end{array}$ & 2017 & $\begin{array}{l}\text { High number of } \\
\text { doctoral graduates. } \\
\text { However, concerns } \\
\text { about the quality. }\end{array}$ & $\begin{array}{l}\text { Active policy to } \\
\text { increase PhD holders } \\
\text { by 2023 }\end{array}$ \\
\hline
\end{tabular}

\section{Demand conditions}

a) Inbound mobility.

China is a country which is considered both a major destination and source country of internationally mobile students. As shown in table 3 below, in 2015 there were 398,000 international students and inbound mobility continues to grow - it has increased by $6 \%$ between 2014 and 2015 (DET, 2016). The inbound mobility ratio is $0.3 \%$ which shows that the number of inbound students is small in comparison to China's HE student population. Malaysia has a strategic objective to become a major destination country for international students and it aims to attract 250,000 international students by 2025 (ICEF Monitor, 2015). In the recent past, the country has entered the top 10 of international student destination countries in the world. In 2014 there were 135,500 international students in Malaysia, up by $13.5 \%$ in comparison to 2013 (ICEF Monitor, 2016). The inbound mobility ratio for 2015 was $7.4 \%$ - that is 7.4 out of 100 students enrolled in Malaysian HE are international students. These findings indicate that both China and Malaysia have positive market prospects for further development of TNE.

b) Outbound mobility.

China is the world's major source country of international students. As shown in table 3, for 2015 UNESCO UIS (2017) reports 790,850 students from China studying overseas. This accounts for $1.8 \%$ of the total HE enrolment in China. The country is primarily an exporter of students, which implies the existence of either push or pull factors that can be addressed with TNE activities. Malaysia historically had been one of the major source countries of international students. In 2015, there were 64,930 students from Malaysia studying overseas (UNESCO UIS, 2017). This was 3\% higher than in 2014 and it accounts for $7.4 \%$ of the total HE enrolments in Malaysia. The country continues to be a prime exporter of students, however, as it is well documented, the outbound mobility trend is slowing down. This reflects the increased capacity of the Malaysian HE sector, where TNE has contributed substantially. Thus, Malaysia appears to be reaching a point of maturity in its TNE market. This may indicate the need for more substantial forms of TNE presence (e.g. IBCs).

c) Capacity of domestic HE system.

The gross enrolment ratio (GER) in 2015 was 83.6 in China and 93.9 in Malaysia (UNESCO UIS, 2017). Both countries have an expanded capacity in the HE systems enabling most of their tertiary age population to access HE. Research indicates (Tsiligiris, 
2014) that as the capacity of the host country's HE system expands, prospective students tend to be more selective about TNE and focus on the quality and reputation of the awarding institution. Thus, for Malaysia, in comparison to China, the higher GER implies a more competitive environment for TNE, and especially for the types of TNE at the lower end of the quality/reputation spectrum.

d) Demographic trend.

The population of 13 to 18 -year-olds as percentage of the total population is $6.6 \%$ in China and 9.4\% in Malaysia (UN, 2017). The world's average for this age group is $9.7 \%$. By 2025, the population in this age group, is expected to grow by $3 \%$ in China but decline by $23.1 \%$ in Malaysia. From a demographic perspective, China is in an upward trend whereas Malaysia is expected to experience a declining pre-HE population in the next years. This implies that TNE providers, along with the other HEIs, in Malaysia will probably have to rely, increasingly, on international student recruitment. In contrast, from the point of view of TNE and education export in China, there is a very strong prospect of uninterrupted growth in the indigenous demand for HE and TNE.

Table 3. Demand conditions analysis for China and Malaysia

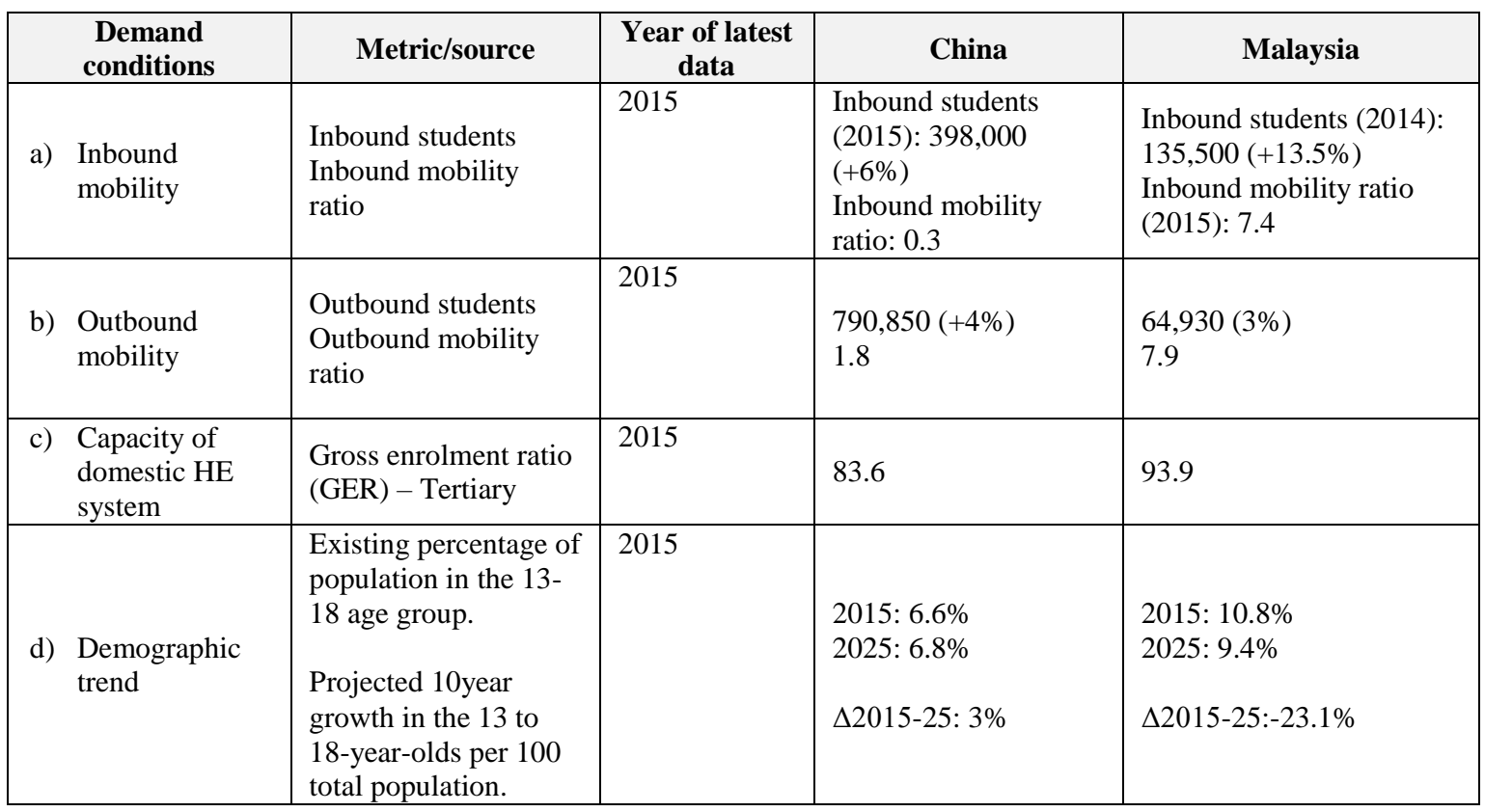

\section{Context for firm rivalry}

a) Government regulation for TNE.

As summarised in table 4 below, China, as one of the top TNE host countries, allows the development and operation of a range of TNE models. However, as outlined by the QAA (2013, p. 9) regulations around TNE in China often change as a result of different policy priorities, which is something that may impact the sustainability of the existing collaborations and arrangements. In Malaysia, the regulatory framework for TNE allows, and actively promotes, all the range of possible TNE activities (British Council and DAAD, 2014). These findings agree with the outcomes of the "Shape of Global HE Vol.2" report, which ranks Malaysia substantially higher than China regarding the openness of higher education systems (Ilieva et al., 2017, p. 10). This explains why Malaysia is hosting a diverse range of TNE activities for major TNE exporting countries, 
such as the UK and Australia. Considering the lower barriers to entry and the stable policy framework in Malaysia, it appears that the TNE market rivalry in Malaysia is more intense in comparison to China.

b) Recognition of TNE qualifications.

In China, the process for the recognition of TNE qualifications can be challenging and unclear. In contrast, as shown in table 4, Malaysia has integrated fully the TNE qualifications in the national qualifications framework. Through the register maintained by the Malaysian Qualifications Agency (2017), Malaysia provides a transparent, and straightforward, mapping of all TNE qualifications offered in the country. This enables prospective students to check the comparability of the TNE qualification with the national HE qualifications. As such, TNE in Malaysia is likely to be considered a direct alternative to domestic and international $\mathrm{HE}$.

c) Ease of doing business.

China scores at the $78^{\text {th }}$ position of the World Bank's "ease of doing business" index (2016). The country is reported to have made progress in simplifying the process for starting a business. The more liberal business environment has contributed to the increase in the number and range of TNE activities in China over the past 20 years. However, the speed of establishment and the type of TNE will be subject to regional and contextual factors (Montgomery, 2016). As summarised in table 4, Malaysia scores high - $23^{\text {rd }}$ out of 190 countries - in the "ease of doing business" index. This reflects the liberal business environment in the country facilitates the establishment of new, and transformation of existing, TNE activities.

d) Income.

For China and Malaysia the GPD per capital in 2016 accounted for $18 \%$ and $22 \%$ of UK's, respectively as shown in table 4 below (World Bank, 2017a). This should be considered carefully by TNE exporting countries and institutions during the planning phase of any TNE activities. There should be a consideration of the programme fee in the context of the local GPD per capital. For example, UK TNE exporting institutions might find it challenging to sustain a partnership in the Chinese market by expecting to receive a normal "international student" tuition fee.

Table 4. Context for rivalry analysis for China and Malaysia

\begin{tabular}{|c|c|c|c|c|}
\hline $\begin{array}{l}\text { Context for Firm } \\
\text { Rivalry }\end{array}$ & Metric & $\begin{array}{c}\text { Year of latest } \\
\text { data }\end{array}$ & China & Malaysia \\
\hline $\begin{array}{l}\text { a) Government } \\
\text { regulation for TNE }\end{array}$ & $\begin{array}{l}\text { Does the country allow } \\
\text { the establishment and } \\
\text { operation of TNE } \\
\text { activities? }\end{array}$ & 2017 & $\begin{array}{l}\text { Positive but often } \\
\text { unclear and subject } \\
\text { to frequent } \\
\text { changes. }\end{array}$ & $\begin{array}{l}\text { Positive and } \\
\text { transparent. }\end{array}$ \\
\hline $\begin{array}{l}\text { b) Recognition of TNE } \\
\text { qualification }\end{array}$ & $\begin{array}{l}\text { Does the country } \\
\text { recognise qualifications } \\
\text { obtained via TNE in the } \\
\text { country? }\end{array}$ & 2017 & $\begin{array}{l}\text { Process can be } \\
\text { challenging and } \\
\text { unclear. }\end{array}$ & $\begin{array}{l}\text { Yes. The process is } \\
\text { clear and } \\
\text { straightforward. }\end{array}$ \\
\hline $\begin{array}{l}\text { c) Ease of doing } \\
\text { business }\end{array}$ & $\begin{array}{l}\text { World Bank's index of } \\
\text { ease of doing business }\end{array}$ & 2016 & $78 / 190$ & $23 / 190$ \\
\hline d) Income & $\begin{array}{l}\text { GPD per capital in } \\
\text { importing country as } \% \text { of } \\
\text { the GPD per capital in } \\
\text { TNE exporting country. }\end{array}$ & 2016 & $18 \%$ & $22 \%$ \\
\hline
\end{tabular}




\section{Summary and conclusions}

Some of the key points emerging by the pilot application of the adapted PDM model for the evaluation of China and Malaysia are:

- China has a liberal regulatory environment for TNE. However, often the regulatory environment is complex and unstable which creates high transaction costs and uncertainty, respectively. TNE exporting institutions which do not consider carefully their tuition fee proposition in ratio to the local income, are likely to face increased competition and challenges in sustaining student recruitment. Demand prospects for TNE in China are strongly positive. However, the sustainability of TNE will be subject to the future policy developments for tackling the high graduate unemployment. TNE exporting institutions, should consider developing, as part of their TNE provision in China, English language support schemes to address the low English language proficiency in the country. Additionally, TNE exporting institutions should consider carefully the local availability of appropriate IT infrastructure before deciding to embark on TNE activities in China.

- Malaysia provides a favourable environment for the establishment and sustainable development of TNE. The positive regulatory environment for TNE in Malaysia creates opportunities as well as challenges for TNE exporting institutions. Entering the Malaysian market is easier and implies opportunities for new entrants but threats for existing providers. Demand prospects for TNE are positive, however in the longer term, there might be challenges due to the shrinking population at HE age. This means that in the future TNE providers might need to rely more on the international student market, which becomes increasingly competitive, and therefore may encounter sustainability issues.

The above summary provides an example of the type of analysis and conclusions that can emerge from the application of the adapted PDM.

This study aimed to introduce an adapted PDM for the evaluation of TNE host countries. The objective of the study was to initiate the process of identifying a core structure of a tool that can be used as the analytical framework of the suitability of a country to act as host of TNE.

The pilot application of the proposed adapted PDM confirmed its applicability in the context of TNE. There are practical challenges in collecting data and identifying alternative metrics for countries where the original metric is not available. This would be especially evident for countries where cross-border activity is underdeveloped, something which is usually coupled by lack of relevant data and statistics.

Despite the potential technical challenges, there is value in the use of the adapted PDM model by TNE exporting institutions or countries as framework of strategic analysis. By combining a range of economic, social, cultural, and educational factors, the adapted PDM provides a more holistic evaluation in comparison to the existing models of TNE host country contextual analysis (e.g. Illieva et al, 2017). As analytical framework, the adapted PDM allows to consider major contextual factors that impact the development and sustainability of TNE activities. Its application, alongside the existing models of analysis, can support TNE exporting institutions to eliminate the various types of risk, which are usually neglected in the decision-making process for the development of TNE activities. 


\section{Limitations and future research}

The adapted PDM is subject to the limitations emerging from the diverse and dynamic nature of TNE activities. Specifically, the implementation of the adapted PDM will be influenced by variant definition of TNE models; the scarcity of data; and the blurring of boundaries between TNE and international student mobility.

The metrics proposed in the adapted PDM are indicative. Further pilot studies are needed to check the consistency of the metrics and adapt them accordingly. Measuring the exact influence of the factors and metrics proposed in the adapted PDM on the actual decisions by exporting institutions is beyond the scope of this research. This should be a topic for future research, which is necessary to operationalise future the adapted PDM. Additionally, the process and the set of factors that affect senior management decisions when selecting a target country for TNE exports is a topic that requires separate investigation. 


\section{References}

ACE. (2015), International Higher Education Partnerships: A Global Review of Standards and Practices, American Council on Education, pp. 1-48.

Akamai. (2017), State of the Internet, pp. 1-63.

Bardhan, A., Jaffee, D.M. and Kroll, C.A. (Eds.). (2013), The Oxford Handbook of Offshoring and Global Employment, 1 edition., Oxford University Press, New York; Oxford.

Biggs, J.B. (1988), “Assessing student approaches to learning”, Australian Psychologist, Vol. 23 No. 2, pp. 197-206.

British Council and DAAD. (2014), Impacts of Transnational Education on Host Countries, pp. $1-76$.

Cheong, K.-C., Hill, C., Fernandez-Chung, R. and Leong, Y.-C. (2016), "Employing the 'unemployable': employer perceptions of Malaysian graduates", Studies in Higher Education, Vol. 41 No. 12, pp. 2253-2270.

Curran, P.J. (2000), "Competition in UK Higher Education: Competitive Advantage in the Research Assessment Exercise and Porter's Diamond Model", Higher Education Quarterly, Vol. 54 No. 4, pp. 386-410.

DET. (2016), China - Outbound and Inbound International Students, Australian Government, Department of Education and Training (DET), p. 1.

Dunning, J.H. (1993), “Internationalizing Porter's diamond”, Management International Review; Wiesbaden, Vol. 33 No. 2, p. 7.

Dutta, S., Lanvin, B. and Wunsch-Vincent, S. (2017), Global Innovation Index 2017, No. Tenth Edition.

Education First. (2016), "EF English Proficiency Index - A comprehensive ranking of countries by English skills", available at: //www.ef.co.uk/epi/ (accessed 2 August 2017).

Emery, V. and Worton, M. (2014), Challenges for the Leadership of Transnational Education in Higher Education: Balancing Risk and Innovation, Leadership Foundation for Higher Education.

Ghemawat, P. (2001), "Distance still matters", Harvard Business Review, Vol. 79 No. 8, pp. $137-147$.

Grant, R.M. (2010), Contemporary Strategy Analysis, 7th ed., John Wiley \& Sons, Hoboken, NJ.

Grapragasem, S., Krishnan, A. and Mansor, A.N. (2014), "Current Trends in Malaysian Higher Education and the Effect on Education Policy and Practice: An Overview", International Journal of Higher Education, Vol. 3 No. 1, pp. 85-93.

Harzing, A.-W. and Giroud, A. (2014), "The competitive advantage of nations: An application to academia", Journal of Informetrics, Vol. 8 No. 1, pp. 29-42.

HE Global. (2016), The Scale and Scope of UK Higher Education Transnational Education, Universities UK, pp. 1-102.

Healey, N.M. (2015), “Towards a risk-based typology for transnational education”, Higher Education, Vol. 69 No. 1, pp. 1-18.

Hoare, L. (2012), "Transnational Student Voices Reflections on a Second Chance", Journal of Studies in International Education, Vol. 16 No. 3, pp. 271-286.

Huang, F. (2017), "Are Chinese PhDs becoming more like US doctorates? - University World News", University World News, 17 March, No. 451, available at: http://www.universityworldnews.com/article.php?story=20170313235214728 (accessed 23 March 2017). 
ICEF Monitor. (2015), "Internationalisation continues to shape the Malaysian education brand", ICEF Monitor - Market Intelligence for International Student Recruitment, 27 November, available at: http://monitor.icef.com/2015/11/internationalisationcontinues-to-shape-the-malaysian-education-brand/ (accessed 3 August 2017).

ICEF Monitor. (2016), "Malaysia competing for a greater share of international students", ICEF Monitor, available at: http://monitor.icef.com/2016/08/malaysia-competinggreater-share-international-students/ (accessed 29 March 2017).

Ilieva, J., Tsiligiris, V., Killingley, P. and Peak, M. (2017), The Shape of Global Higher Education (Vol. 2): International Mobility of Students, Research and Education Provision, British Council, London, pp. 1-40.

Lawton, W. and Jensen, S. (2015), An Early-Warning System for TNE. Understanding the Future Global Network Connectivity and Service Needs of UK Higher Education, igraduate, pp. 1-31.

Lawton, W. and Katsomitros, A. (2012), International Branch Campuses. Data and Developments, The Observatory on Borderless Higher Education, London, pp. 1-88.

Levatino, A. (2016), "Transnational higher education and international student mobility: determinants and linkage", Higher Education, Vol. 73 No. 5, pp. 1-17.

Li, S., Whalley, J. and Xing, C. (2014), "China's higher education expansion and unemployment of college graduates", China Economic Review, Vol. 30, pp. 567-582.

Lindsay, V. and Antoniou, C. (2016), "Applying foreign entry market strategies to UK higher education transnational education models", Perspectives: Policy and Practice in Higher Education, Vol. 20 No. 2-3, pp. 51-58.

Marginson, S., Kaur, S., Sawir, E., Ziguras, C. and McBurnie, G. (2011), “Transnational Higher Education in the Asia-Pacific Region: From Distance Education to the Branch Campus", in Marginson, S., Kaur, S., Sawir, E., Maassen, P. and Müller, J. (Eds.), Higher Education in the Asia-Pacific, Vol. 36, Springer Netherlands, pp. 105-122.

McBurnie, G. and Ziguras, C. (2007), Transnational Education: Issues and Trends in Offshore Higher Education, Routledge, New York NY.

MIDA. (2017), "Higher Education Ministry maintains aim of producing 60,000 $\mathrm{PhD}$ holders by 2023", Malaysian Investment Development Authority, available at: http://www.mida.gov.my/home/3311/news/higher-education-ministry-maintains-aimof-producing-60-000-phd-holders-by-2023-/ (accessed 3 August 2017).

Montgomery, C. (2016), "Transnational partnerships in higher education in China: The diversity and complexity of elite strategic alliances", London Review of Education, Vol. 14 No. 1, pp. 70-85.

Moon, H., Rugman, A. and Verbeke, A. (1995), "The generalized double diamond approach to international competitiveness", Research in Global Strategic Management, Vol. 5, Elsevier, pp. 97-114.

MQA. (2017), "Malaysian Qualifications Register", available at: http://www2.mqa.gov.my/mqr/ (accessed 3 August 2017).

OECD. (2015a), "PISA - Programme for International Student Assessment", OECD, available at: http://www.oecd.org/pisa/ (accessed 2 August 2017).

OECD. (2015b), "Employment by education level", OECD Data, available at: http://data.oecd.org/emp/employment-by-education-level.htm (accessed 3 August 2017).

Porter, M.E. (1990), The Competitive Advantage of Nations, Free Press, New York.

QAA. (2012), UK Quality Code for Higher Education. Part B: Assuring and Enhancing Academic Quality. Chaper B10: Managing Higher Education Provision with Others, The Quality Assurance Agency for Higher Education, Cloucester, pp. 1-53. 
QAA. (2013), Review of UK Transnation Education in China 2012: Overview, The Quality Assurance Agency for Higher Education, available at: http://www.qaa.ac.uk/en/Publications/Documents/TNE-China-Overview.pdf.

Rugman, A.M. and D'Cruz, J.R. (1993), “The 'Double Diamond' Model of International Competitiveness: The Canadian Experience”, MIR: Management International Review, Vol. 33, pp. 17-39.

Sa, C., Florax, R.J. and Rietveld, P. (2004), "Determinants of the regional demand for higher education in the Netherlands: A gravity model approach", Regional Studies, Vol. 38 No. 4, pp. 375-392.

Shams, F. and Huisman, J. (2012), "Managing Offshore Branch Campuses: An Analytical Framework for Institutional Strategies", Journal of Studies in International Education, Vol. 16 No. 2, pp. 106-127.

Stafford, S. and Taylor, J. (2016), "Transnational education as an internationalisation strategy: meeting the institutional management challenges", Journal of Higher Education Policy and Management, Vol. 38 No. 6, pp. 625-636.

Stonkiene, M., Matkeviciene, R. and Vaiginiene, E. (2016), "Evaluation of the national higher education system's competitiveness: Theoretical model”, Competitiveness Review; Bingley, Vol. 26 No. 2, pp. 116-131.

Tomlinson, M. (2016), "The impact of market-driven higher education on student-university relations: Investing, consuming and competing", Higher Education Policy, Vol. 29 No. 2, pp. 149-166.

Tsiligiris, V. (2014), Transnational Education vs International Student Mobility: Substitutes or Distinct Markets?, The Observatory on Borderless Higher Education, pp. 1-53.

Tsiligiris, V. (2015), Cross-Border Higher Education and Quality Management, Ph.D., Birmingham City University, available at: http://ethos.bl.uk/OrderDetails.do?did=1\&uin=uk.bl.ethos.638451 (accessed 24 April 2016).

UN. (2017), "World Population Prospects", United Nations, Population Unit, available at: https://esa.un.org/unpd/wpp/DataQuery/ (accessed 29 March 2017).

UNESCO UIS. (2017), “Data Centre: Education”, Institute of Statistics, available at: http://stats.uis.unesco.org/unesco/tableviewer/document.aspx?ReportId=143 (accessed 8 July 2017).

Verbik, L. (2007), "The International Branch Campus: Models and Trends", International Higher Education, No. 46.

WEF. (2016), “The Human Capital Report 2016”, World Economic Forum, Geneva, pp. 1307.

Wilkins, S. (2016a), "Establishing international branch campuses: a framework for assessing opportunities and risks", Journal of Higher Education Policy and Management, Vol. 38 No. 2, pp. 167-182.

Wilkins, S. (2016b), "Transnational Higher Education in the 21st Century", Journal of Studies in International Education, Vol. 20 No. 1, pp. 3-7.

Wilkins, S. and Huisman, J. (2012), "The international branch campus as transnational strategy in higher education", Higher Education, Vol. 64 No. 5, pp. 627-645.

Wilkins, S. and Urbanovič, J. (2014), "English as the Lingua Franca in Transnational Higher Education Motives and Prospects of Institutions That Teach in Languages Other Than English", Journal of Studies in International Education, Vol. 18 No. 5, pp. 405-425.

World Bank. (2016), Doing Business 2017: Equal Opportunity for All, The World Bank, available at:https://doi.org/10.1596/978-1-4648-0948-4.

World Bank. (2017a), "World Bank Data", available at: http://data.worldbank.org/ (accessed 3 August 2017). 
World Bank. (2017b), "Ranking of economies - Doing Business - World Bank Group", available at: http://www.doingbusiness.org/rankings (accessed 3 August 2017).

Yang, J. and Wang, Y. (2016), Tuition Fees and Student Mobility, Lund University, available at: https://lup.lub.lu.se/student-papers/search/publication/8619324 (accessed 17 March 2017).

Ziguras, C. (2016), "The Expansion of Cross-Border Graduate Education in the Asia Pacific: Developmental and Financial Challenges", in Neubauer, D.E. and Buasuwan, P. (Eds.), Asia Pacific Graduate Education, Palgrave Macmillan US, pp. 19-35.

Ziguras, C. and McBurnie, G. (2015), "Private Higher Education in Greece: Protests Against Recognition”, International Higher Education, No. 45.

Notes

\footnotetext{
' The OLI model explains the multination activity of firms as function of three theories of foreign direct investment. Specifically, "O" stands for the firm specific advantages; " $\mathrm{L}$ " stands for the country specific advantages; and "I" stands for the internalisation advantages.

ii There is not graduate employment data available on the OECD datacenter for any of the countries in this pilot study. Data from alternative sources has been used.

iii There is not data for the metric "The percentage of population (age 25 and over) with a completed doctoral or equivalent degree (ISCED 8)" available on the OECD datacenter for any of the countries in this pilot study. Data from alternative sources has been used.
} 